\title{
A New Model of Productive Online Discussion and Its Implications for Research and Instruction
}

\author{
Fei Gao \\ Montclair State University, USA \\ Charles Xiaoxue Wang \\ Georgia State University, USA \\ Yanling Sun \\ Montclair State University, USA
}

\begin{abstract}
We develop a new model of productive online discussion based on a brief review of research literature on online discussion. As compared to previous discussion models, the new model provides a more systematic and comprehensive framework to understand how learning occurs through online discussion. Based on the new model, we propose several directions for research on improving the quality of online discussion and learning.
\end{abstract}

Keywords: productive online discussion, discussion model, online learning

\section{Introduction}

Online learning is transforming education in K-12, higher education, and lifelong learning. There has been an accelerating trend in the development of online courses and hybrid learning environments. This rapid evolution has outpaced the capacity of the educational research community to evaluate the consequences of this phenomenon.

Asynchronous discussion is one of the major means to support student learning in online courses (Joeng, 2003). This form differs from traditional classroom discussion in several ways. Some researchers argue that asynchronous discussion supports a more decentralized and collaborative learning environment, whereby the teacher acts as a facilitator and students take responsibility for their own learning (Jonassen, Davidson, Collins, Compbell, \& Hagg, 1995). In addition, online discussion tools automatically keep written records of the discussion, providing learners with more opportunities to identify, examine, and make connections between ideas. Asynchronous discussion also frees the learners from time and space constraints, providing more time for reflection and increasing the chances of in-depth thinking occurring (Anderson, 1996; Collison, Elbaum, Haavind, \& Tinker, 2000).

In reality, however, high quality learning through participating in asynchronous online 
discussions is hard to achieve. Researchers have reported that online discussions very often failed to support high level of knowledge construction (Kanuka \& Anderson, 1998) or truly conversational modes of learning (Thomas, 2002). Though various factors contribute to such a failure, we argue that a pedagogically sound model that conceptualizes what constitute as a productive online discussion would eliminate some of these factors and facilitate student learning through online discussions. Without understanding the essential qualities of a productive online discussion, promoting these qualities during the discussions is difficult, and therefore, the discussions often fail to accomplish the desired learning goals. This paper reviews current research on online discussion, proposes a comprehensive model of productive online discussion, and discusses the implications of the new model for research and instruction.

\section{Research on Online Discussion}

Based on a few recent reviews of research on online education (Hill, Song, \& West, 2009; Tallent-Runnels et al., 2006; Wever, Schellens, Valcke, \& Keer, 2006), this recent research on promoting online discussions has primarily focused on three major aspects of online discussion: (1) cognitive processes, (2) argumentation, and (3) social knowledge construction.

\subsection{Cognitive Processes}

Henri's (1992) multi-dimensional model specified cognitive skills-elementary clarification, in-depth clarification, inference, judgment, and strategies-as represented in online posts, taking the occurrence of such cognitive processes as evidence that learning was taking place. Newman, Johnson, Cochrane, and Webb (1995), building upon Henri (1992) and other researchers' work, identified particular kinds of critical thinking processes, such as linking ideas, justification, and critical assessment, and looked for evidence of these processes in the postings of individuals.

To improve the level of cognitive processes in online discussion, researchers have designed specific discussion environments or taught participants particular discussion strategies. In Guzdial (2000), students chose for each post a post type or classification, such as a new theory or evidence. Knowledge Forum,previously called CSILE (Scardamalia \& Bereiter, 2003), supports both the creation of notes and the ways they are displayed, linked, and made objects of further work. The rationale is that a prompt suggesting a specific type of post will support students' metacognitive thinking, helping them engage in certain cognitive processes (Scardamalia \& Bereiter, 1994). In online discussions studied by Choi, Land, and Turgeon (2005), the instructor provided guidelines for generating three types of questions to promote peer interaction and enhance the quality of online discussion: (1) clarification or elaboration questions, (2) counter-arguments, and (3) context- or perspective-oriented questions. This intervention resulted in an increase in the frequency of questioning, but did not affect the quality of the discussion. Similarly, Yang, Newby, and Bill (2005) had the instructor teach and model Socratic questioning in their research, which then in turn the students then used in their online discussions. This approach resulted in more posts made to the discussions that verified critical thinking occured.

\subsection{Argumentation}

Some researchers have aimed at studying the argumentation processes in online discussions. In Garrison, Anderson, and Archer's (2000) model of cognitive presence, argumentation or critical thinking consists of four steps: (1) a triggering event, which leads to "a state of dissonance or a feeling of unease resulting from 
an experience"; (2) "searching for clarification and attempting to orient one's attention"; (3) "integrating the information and knowledge into a coherent idea or concept"; and (4) "the resolution of the issue or problem" (p. 98-99).

Researchers have studied various ways of supporting coherent argument in online discussions. For example, in a constrained discussion environment, participants must label each of their posts using a predefined set of message types (Cho \& Jonassen, 2002; Jeong \& Joung, 2007; Moore \& Marra, 2005), which served as scaffolds for the content of their postings in online debates. Suthers and colleagues have explored the use of graphical representations to support arguments and knowledge construction during discussion (Suthers, Weiner, Connelly, \& Paolucci, 1995). In their work, an online environment was created in which students could collaboratively create a knowledge-map of a particular topic. In the activity, students were required to classify their posts as a certain type and chose to place the post in relation to other posts. Nussbaum and colleagues (2004) encouraged counterarguments in online discussion by asking students to choose such note starters as "on the opposite side," or "I need to understand," which successfully increased the frequency of disagreement and student willingness to consider other points of view.

\subsection{Social Knowledge Construction}

A number of researchers have documented the processes of knowledge construction in asynchronous online discussions. For example, Gunawardena et al. (1997) proposed an interaction analysis model for examining social construction of knowledge in online discussions. They identified student posts reflecting the five stages of co-construction of knowledge: (1) "sharing/comparing of information;" (2) "discovery and exploration of dissonance or inconsistency among ideas, concepts or statements;" (3) "negotiation of meaning/co-construction of knowledge;" (4) "testing and modification of proposed synthesis or co-construction;" and (5) "agreement statement(s)/application of newly constructed meaning" (p. 414). Similarly, Pena-Shaff and Nicholls (2004) developed an instrument with 11 categories, such as question, reply, clarification, and reflection, to capture the knowledge construction processes.

Researchers have also developed ways to promote the level of social knowledge construction in online discussion. Lebaron and Miller (2005) reported the effect of role play in online discussion, whereby each participant of the role-playing team assumed a different role. They concluded that role play might be a discussion activity that helps to encourage construction of knowledge in online learning environments. Gilbert and Dabbagh (2005) tried three types of structures in an online course, and found that certain elements of structure such as explicit facilitator guidelines and evaluation rubrics have had a positive impact on online construction of knowledge. Rourke and Anderson (2002) studied the effects of asking students to lead discussions. Students perceived these discussions led by their peers as more structured, more fluid, more responsive, and more interesting than those led by the instructor, even though there was little difference in the quality of discussion as assessed by the researchers.

\subsection{Summary}

This research has provided important insights into how students interact and engage with others in online environments and how the learning environment can be structured to promote high quality discussion, discussion that engages participants with content, and promotes learning. Each line of research, 
however, has focused on only one specific aspect of online discussion. To fully understand what productive discussion includes, a more comprehensive model is needed.

\section{A New Model of Productive Online}

\section{Discussion}

Although discussion in online courses is valued by many, the characteristics of productive discussions have seldom been made explicit. We define productive discussions as those that engage students in meaningful learning. According to Bridges (1988), the central purpose of discussion in most educational settings is to foster the development of knowledge, understanding or judgment of its participants on the matter under discussion (p. 17). In other words, a productive discussion is one that leads to effective knowledge acquisition.

Previous review of research on online discussion has revealed that researchers have paid attention to three major aspects of online discussion: (1) cognitive processes, (2) argumentation, and (3) social knowledge construction. Not difficult to find, each line of research is based on a different theoretical perspective on how knowledge is acquired.

Researchers who take the perspective of cognitive psychology have focused on the cognitive processes in online discussion and their relations to learning. This perspective suggests that information is more likely to be understood or retained when the individual is actively engaged in cognitive activities such as questioning, interpreting, elaborating or relating the information to his or her prior knowledge ( Anderson \& Biddle, 1975; Collins, Brown, \& Larkin, 1980; Pressley, Wood, Woloshyn, \& Martin, 1992). Individuals who are asked to provide interpretative and elaborate explanations have understand more and construct better mental models of the content than do individuals who provide less sophisticated statements (Webb, 1991). This finding is supported by empirical studies on self-explanation (Chi, Bassok, Lewis, Reimann, \& Glaser, 1989; Chi, de Leeuw, Chiu, \& LaVancher, 1994; Chi \& VanLehn, 1991; Collins et al., 1980; VanLehn, Jones, \& H., 1992), and higher-order questioning (Redfield \& Rouseau, 1981; Samson, Strykowski, Weinstein, \& Walberg, 1987; Wong, 1985). Therefore, a good discussion in this regard should promote learners to engage in these cognitive processes such as interpretation, elaboration, and making connections with prior knowledge.

Researchers who have emphasized the role of argumentation in online discussions represent the individual constructivist perspective. From this perspective, cognitive development originates from cognitive conflict created by social interaction. The conflict between the individual's existing understanding and new experiences creates a disequilibration, which in turn, leads the individual to question original assumptions and to "go beyond his current state and strike out in new directions" (Piaget, 1985, p.10). Evidently, this disequilibration could be evoked when individuals are interacting with either texts or peers. Related studies on peer collaboration and discourse have shown that conflicting views in peer interaction are more likely to encourage the knowledge building process and conceptual change among learners (Chan, 2001; Chan, Burtis, \& Bereiter, 1997). Peer interactions are debilitating when the statements that should have caused conflict are ignored or treated superficially. In contrast, conflicting statements are usually carefully addressed and developed in a productive discourse (Palincsar, 1986). Based on this perspective, a good discussion should involve carefully examination and evaluation of conflicting views. 
Researchers who have studied the social knowledge construction processes in online discussions approach the process from the social constructivist perspective. From this perspective, individuals do not learn in isolation from others. Each individual may conceive of the external reality somewhat differently, based on their unique prior experiences with the world and their beliefs about them (Jonassen, 1991). Through social interaction and collaboration, individuals share perspectives, integrate personal experiences, personal interpretations of the world with the perspectives of others, and allow their understandings to change and evolve during the discussion. Therefore, this perspective suggests that a productive discussion occurs when the participants keep an open mind to multiple perspectives (coming from both texts and other participants), and are always ready to negotiate meaning and improve their understandings.

These three perspectives offer distinct but complementary understandings of how people could learn through online discussion. Many online discussions present a unique combination of three perspectives of learning, so attending to all these three aspects of learning should better facilitate our thinking about how learning is occurring in online discussion. We argue that all these three aspects are crucial for online discussion and learning. Therefore, a productive online discussion model should take into consideration all the three aspects. To summarize, in a productive discussion, learners should:

a) discuss to comprehend - actively engage in such cognitive processes as interpretation, elaboration, and making connections with prior knowledge;

b) discuss to critique - carefully examine other people's views, and be sensitive and analytical to conflicting views; c) discuss to construct knowledge actively negotiate and construct meanings, and reconsider, refine, and sometimes revise their thinking.

In addition, discussion differs from many other forms of learning in that discussion not only records learning processes but also demonstrates learning outcomes. We believe that in a productive online discussion, students will demonstrate their improved understandings through a variety of behaviors or actions. Therefore, in a productive discussion, learners should also:

d) discuss to share improved understanding - actively synthesize knowledge and explicitly express improved understanding based on a review of previous discussions.

According to these principles, we developed the productive online discussion model (see Table 1 on pp. 70-72). The model indicates that different dispositions of discussions are interrelated and one disposition of discussions would facilitate another as shown in Figure 1 on the next page.

\section{Implications for Facilitating Online}

\section{Discussions}

Defining what a productive online discussion should be and building a model for productive online discussion is a necessary precursor to research on improving and evaluating the quality of online discussions (Spatariu, Hartley, \& Bendixen, 2004). Based on this new model of productive online discussion, we discuss several implications for instructors and researchers of discussion-centered online learning environments. Table 2 on the page 7273 presents the possible instructional strategies that can be used to promote the four dispositions 


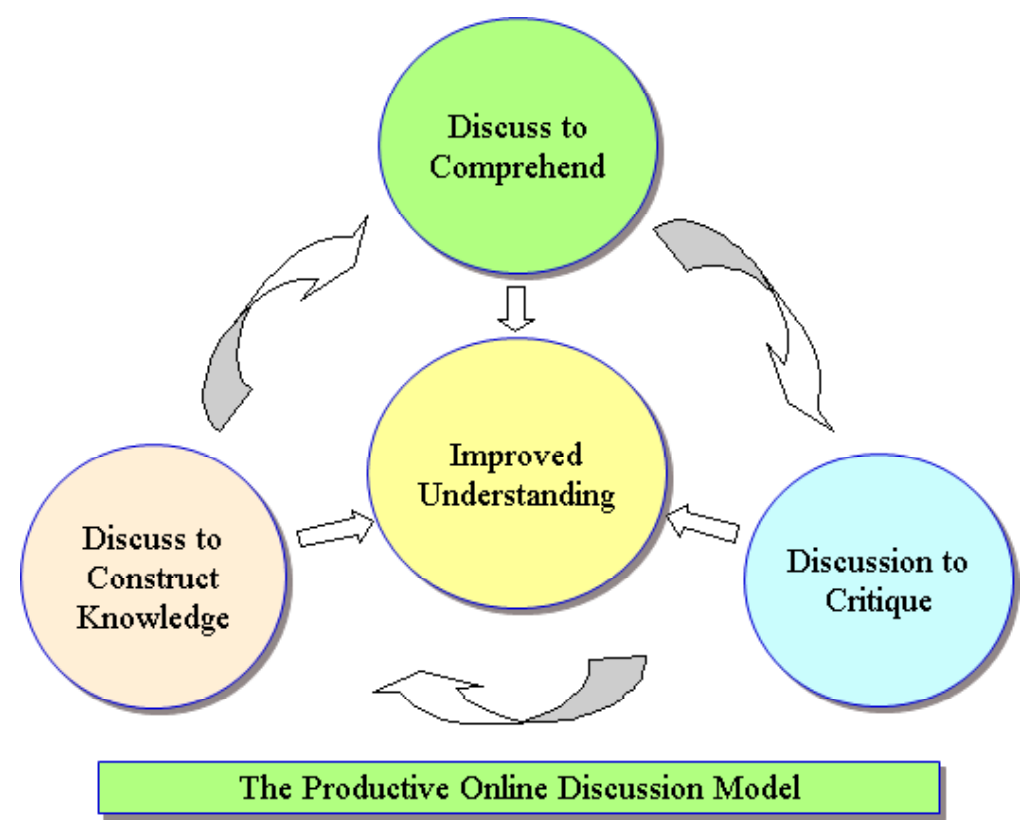

Figure 1. Productive Online Discussion Model

Table 1. Productive Online Discussion Model

\begin{tabular}{|l|l|}
\hline \multicolumn{2}{|c|}{ Productive Online Discussion Model } \\
\hline $\begin{array}{l}\text { Disposition 1: Discuss to Comprehend } \\
\text { Actively engage in such cognitive processes as interpretation, elaboration, making } \\
\text { connections to prior knowledge. }\end{array}$ \\
\hline \multicolumn{1}{|c|}{ Learner Actions } & \multicolumn{1}{c|}{ Discussion Samples* } \\
\hline $\begin{array}{l}\text { (a) Interpreting } \\
\text { or elaborating the } \\
\text { ideas by making } \\
\text { connection to the } \\
\text { learning materials }\end{array}$ & $\begin{array}{l}\text { I thought Resnick's (1987) discussion on the role of schooling in } \\
\text { our contemporary society was valuable. The author's argument, that } \\
\text { schools should prepare versatile persons who can adapt in the ever- } \\
\text { changing working environment, seemed to resonate the ideas of self- } \\
\text { directed, "adaptive" learning. }\end{array}$ \\
\hline $\begin{array}{l}\text { (b) Interpreting } \\
\text { or elaborating the } \\
\text { ideas by making } \\
\text { connection to } \\
\text { personal experience }\end{array}$ & $\begin{array}{l}\text { kwhat I appreciate about his ideas is the importance of prior } \\
\text { knowledge in the act of learning and more relevantly, in the scheme } \\
\text { of teaching...Most of my students lived at or below poverty and } \\
\text { many were refugees or immigrants from Somalia, Eritrea, Vietnam, } \\
\text { Cambodia, and other African and Southeast Asian countries. Their } \\
\text { experiences and the environments they grew up in were very } \\
\text { different than that of an average American student and very different } \\
\text { than my own. As a result, it was very important for me to take into } \\
\text { consideration the diversity in prior knowledge that abounded in the } \\
\text { classroom... }\end{array}$ \\
\hline
\end{tabular}




\begin{tabular}{|l|l|}
\hline $\begin{array}{l}\text { (c) Interpreting } \\
\text { or elaborating the } \\
\text { ideas by making } \\
\text { connection to other } \\
\text { ideas, sources, or } \\
\text { references }\end{array}$ & $\begin{array}{l}\text {...Finally, anthropologists and other scholars also support the same } \\
\text { concept as Locke. For example, the anthropologist Mary Catherine } \\
\text { Bateson determined from her work with several cultures that making } \\
\text { meaningful connections between life experiences are necessary for } \\
\text { us to learn (Bateson, 1994). She states that limiting our attention } \\
\text { hampers the ability to learn by limiting perceptions and experiences } \\
\text { to reference and reflect. }\end{array}$
\end{tabular}

\section{Disposition 2: Discuss to Critique}

Carefully examine other people's views, and be sensitive and analytical to conflicting views.

\begin{tabular}{|l|l|}
\hline \multicolumn{1}{|c|}{ Learner Actions } & \multicolumn{1}{c|}{ Discussion Samples* } \\
\hline $\begin{array}{l}\text { (a) Building or } \\
\text { adding new insights } \\
\text { or ideas to others' } \\
\text { posts }\end{array}$ & $\begin{array}{l}\text { I so agree with you that learning depends on experiences. It helps if it } \\
\text { can be related to some past experience. I think learning also depends } \\
\text { on motivation as well as what other things may be going in the home } \\
\text { especially with children... }\end{array}$ \\
\hline $\begin{array}{l}\text { (b) Challenging the } \\
\text { ideas in the texts }\end{array}$ & $\begin{array}{l}\text {.. If Plato's theory would be correct then what (if anything) lies in } \\
\text { our future. Will there be no more major revolutions or discoveries? } \\
\text { Since all that IS known is already known by those who know it, could } \\
\text { it be that there is nothing more to know? }\end{array}$ \\
\hline $\begin{array}{l}\text { (c) Challenging the } \\
\text { ideas in others' posts }\end{array}$ & $\begin{array}{l}\text { When talking about your children, you say 'I would have expected } \\
\text { to see a difference in their learning and development." Are you really } \\
\text { saying that you don't see significant differences in your children's } \\
\text { learning and development? I think of my twin nephews, who } \\
\text { obviously were born and raised together, but somehow were very } \\
\text { different from long before age one in what they valued and what } \\
\text { stimuli they responded to. There was clearly an in-born difference. In } \\
\text { their case, it was clearly never a matter of being taught differently or } \\
\text { having exposure to different environments. }\end{array}$ \\
\hline
\end{tabular}

Disposition 3: Discuss to Construct Knowledge

Actively negotiate meanings, and be ready to reconsider, refine and sometimes revise their thinking.

\begin{tabular}{|l|l|}
\hline \multicolumn{1}{|c|}{ Learner Actions } & \multicolumn{1}{c|}{ Discussion Samples* } \\
\hline $\begin{array}{l}\text { (a) Comparing and } \\
\text { contrasting views } \\
\text { from the texts or } \\
\text { others' posts }\end{array}$ & $\begin{array}{l}\text { I really liked the way you took what we have been calling a "faith- } \\
\text { based" theory and put it into biological terms. I don't agree with } \\
\text { Plato's theory entirely, but you are right, the brain is a system that } \\
\text { works better in some than in others. }\end{array}$ \\
\hline $\begin{array}{l}\text { (b) Facilitating } \\
\text { thinking and } \\
\text { discussions by } \\
\text { raising questions }\end{array}$ & $\begin{array}{l}\text { My question is this - why do our schools focus so much on theory? Is } \\
\text { it because they are run by professors who are enthralled with "theory" } \\
\text { rather than actual practice? This is puzzling to me. How have our } \\
\text { schools gotten to the point they are now in teaching more theory than } \\
\text { practical experience? }\end{array}$ \\
\hline
\end{tabular}


(c) Refining and revising one's own view based on the texts or others' posts
...The article also helped me to realize the importance of being a continual learner and that even when I am in the field, that I need to be continually enhancing my practices through research and learning.

\section{Disposition 4: Discuss to Share Improved Understanding}

Actively synthesize knowledge and explicitly express improved understanding based on a review of previous discussions.

\begin{tabular}{|l|l|}
\hline \multicolumn{1}{|c|}{ Learner Actions } & \multicolumn{1}{c|}{ Discussion Samples* } \\
\hline $\begin{array}{l}\text { (a) Summarizing } \\
\text { personal learning } \\
\text { experiences of online } \\
\text { discussions }\end{array}$ & $\begin{array}{l}\text { Before the discussion, I really don't have the answer either! After } \\
\text { reading all your postings, I realize that there is a way to have a balance } \\
\text { between the two; perhaps being introduced to social interaction in the } \\
\text { classroom and applying it outside of the classroom? }\end{array}$ \\
\hline $\begin{array}{l}\text { (b) Synthesizing } \\
\text { discussion contents }\end{array}$ & $\begin{array}{l}\text { I think that it's interesting that the three of us that have posted thus far } \\
\text { have all talked about repetition as a means for long-term memory, and } \\
\text { we all had different examples of it. I wonder if this is because as we } \\
\text { grow up, we have all learned that one of the best ways to remember } \\
\text { information for the long-term is to repeat it over and over until it is } \\
\text { almost like second nature and we can recall it whenever we need to. }\end{array}$ \\
\hline $\begin{array}{l}\text { (c) Generating new } \\
\text { topics based on a } \\
\text { review of previous } \\
\text { discussions }\end{array}$ & $\begin{array}{l}\text { This is pretty interesting! So far we have all agreed that if there is personal } \\
\text { meaning associated with the learning content, student attention and memory } \\
\text { will improve. What does this mean for us as future teachers? }\end{array}$ \\
\hline
\end{tabular}

* Discussion samples were selected from student online discussions in several online education courses.

Table 2. Productive Discussion Model

\begin{tabular}{|c|c|c|}
\hline \multicolumn{3}{|c|}{ Productive Discussion Model } \\
\hline Dispositions & Learner Actions & Instructional Strategies \\
\hline $\begin{array}{l}\text { Actively engage } \\
\text { in such cognitive } \\
\text { processes as } \\
\text { interpretation, } \\
\text { elaboration, } \\
\text { and making } \\
\text { connections with } \\
\text { prior knowledge. }\end{array}$ & $\begin{array}{l}\text { (a) Interpreting or elaborating } \\
\text { the ideas by making } \\
\text { connection to the learning } \\
\text { materials } \\
\text { (b) Interpreting or elaborating } \\
\text { the ideas by making } \\
\text { connection to personal } \\
\text { experience } \\
\text { (c) Interpreting or elaborating } \\
\text { the ideas by making } \\
\text { connection to other ideas, } \\
\text { sources, or references }\end{array}$ & $\begin{array}{l}\text { (a) Teaching discussion strategies that } \\
\text { encourage active cognitive processing } \\
\text { during discussions } \\
\text { (b) Designing discussion environments } \\
\text { that promote these actions } \\
\text { (c) Designing discussion activities that } \\
\text { encourage active cognitive processing } \\
\text { (d) Developing discussion rubrics } \\
\text { or guidelines to scaffold student } \\
\text { discussion and provide assessment } \\
\text { tools }\end{array}$ \\
\hline
\end{tabular}




\begin{tabular}{|c|c|c|}
\hline $\begin{array}{l}\text { Carefully } \\
\text { examine other } \\
\text { people's views, } \\
\text { and be sensitive } \\
\text { and analytical } \\
\text { to conflicting } \\
\text { views. }\end{array}$ & $\begin{array}{l}\text { (a) Building or adding new } \\
\text { insights or ideas to others' } \\
\text { posts } \\
\text { (b) Challenging the ideas in } \\
\text { the text } \\
\text { (c) Challenging the ideas in } \\
\text { others' posts }\end{array}$ & $\begin{array}{l}\text { (a) Teaching discussion strategies that } \\
\text { encourage critical thinking and } \\
\text { argumentation during discussions } \\
\text { (b) Designing discussion environments } \\
\text { that promote these actions } \\
\text { (c) Designing discussion activities that } \\
\text { encourage critical thinking and } \\
\text { argumentation } \\
\text { (d) Developing discussion rubrics } \\
\text { or guidelines to scaffold student } \\
\text { discussion and provide assessment } \\
\text { tools }\end{array}$ \\
\hline $\begin{array}{l}\text { Actively } \\
\text { negotiate } \\
\text { meanings, } \\
\text { and be ready } \\
\text { to reconsider, } \\
\text { refine, and } \\
\text { sometimes } \\
\text { revise their } \\
\text { thinking. }\end{array}$ & $\begin{array}{l}\text { (a) Comparing and contrasting } \\
\text { views from the text or } \\
\text { others' posts } \\
\text { (b) Facilitating thinking and } \\
\text { discussions by raising } \\
\text { questions } \\
\text { (c) Refining and revising } \\
\text { one's own view based on } \\
\text { the texts or others' posts }\end{array}$ & $\begin{array}{l}\text { (a) Teaching discussion strategies } \\
\text { that encourage active knowledge } \\
\text { construction during discussions } \\
\text { (b) Designing discussion environments } \\
\text { that promote these actions } \\
\text { (c) Designing discussion activities } \\
\text { that encourage active knowledge } \\
\text { construction } \\
\text { (d) Developing discussion rubrics } \\
\text { or guidelines to scaffold student } \\
\text { discussion and provide assessment } \\
\text { tools }\end{array}$ \\
\hline $\begin{array}{l}\text { Actively } \\
\text { synthesize } \\
\text { knowledge } \\
\text { and explicitly } \\
\text { express } \\
\text { improved } \\
\text { understanding } \\
\text { based on a } \\
\text { review of } \\
\text { previous } \\
\text { discussions. }\end{array}$ & $\begin{array}{l}\text { (a) Summarizing personal } \\
\text { learning experiences of } \\
\text { online discussions } \\
\text { (b) Synthesizing discussion } \\
\text { content } \\
\text { (c) Generating new topics } \\
\text { based on a review of } \\
\text { previous discussions }\end{array}$ & $\begin{array}{l}\text { (a) Teaching discussion strategies that } \\
\text { encouraging summarizing and } \\
\text { synthesizing during discussions } \\
\text { (b) Designing discussion environments } \\
\text { that promote these actions } \\
\text { (c) Designing discussion activities } \\
\text { that encourage summarizing and } \\
\text { synthesizing } \\
\text { (d) Developing discussion rubrics } \\
\text { or guidelines to scaffold student } \\
\text { discussion and provide assessment } \\
\text { tools }\end{array}$ \\
\hline
\end{tabular}


described in our productive online discussion model.

\subsection{Developing Discussion Strategies}

The new model of productive online discussion has provided a framework for developing a set of discussion strategies for students to use in online discussions. Researchers have considered ways of teaching students strategies to interact with each other in online discussion. But most of them focus on the strategy of questioning (Choi et al., 2005; Yang et al., 2005). We argue that to enhance the quality of learning in online discussions, teaching students one single strategy is not enough. Researchers and instructors should develop and teach students multiple online discussion strategies to promote the quality of discussion and learning. The new model, rooted in three grand learning theories, has provided direction to developing the types of strategies essential for learning. In Gao et al.'s (submitted) study, for example, students were taught five discussion strategies developed from the productive discussion model, and were asked to label their posts with post types indicating the strategies used. The explicit instruction on discussion strategies led to an improvement in the quality of discussion.

\subsection{Designing Online Discussion}

\section{Environments}

Researchers studying online discussion have examined how the design of the discussion environment impacts the nature of online discussions. The constraint discussion environment (Cho \& Jonassen, 2002; Jeong \& Joung, 2007; Moore \& Marra, 2005), for example, is designed in such ways that guide learners to develop coherent argumentation. Current research on promoting productive online discussion through the design of the environments, however, has focused on how to encourage one particular quality of good discussion. The new model suggests twelve interrelated actions that are crucial for a productive online discussion, which offers guidelines for designing environments that support a productive online discussion. For example, certain environment can be designed and developed to encourage multiple qualities of productive discussion.

\subsection{Designing Discussion Activities}

A few researchers have designed discussion activities to promote a certain kind of learning. Kanuka, Rourke, and Laflamme (2006), for example, studied the relative influence of five discussion activities on online discussions: (1) nominal group technique; (2) debate; (3) invited expert; (4) WebQuest; and (5) reflective deliberation. They found that students posted a higher proportion and number of messages reflective of the highest levels of cognitive presence when they engaged in the WebQuest and debate activities. Similar to research on the design of discussion environment, existing literature on designing discussion activities has focused on how an activity supports a particular quality of discussion. The productive online discussion model suggest that future research is needed to understand how the design of discussion activities affects multiple aspects of participant learning in terms of (a) cognitive processes, (b) argumentation, and (c) social knowledge construction.

\subsection{Developing Discussion Rubrics and Guidelines}

Various content analysis rubrics have been developed to examine the quality of online discussions. Many of them, however, have emphasized on one particular aspect of learning. For example, Gunawardena and colleagues' (1997) model emphasizes on the social knowledge construction aspect of 
the discussion, and Newman et al. (1995) focus on the critical thinking demonstrated in online discussion. There is a need for a comprehensive and systematic model to guide student discussion and to analyze discussions. The productive online discussion model can be modified and used as discussion guidelines or as evaluation rubrics to scaffold student discussion, or to better understand different types of learning that occurs in online discussion. More importantly, establishing a common understanding of what constitutes a high-quality discussion will make comparisons of the quality of discussions across various studies easier, which is now extremely hard, as different studies report different measures for the quality of discussion.

\section{Conclusion}

Most existing online discussion models attend to only one aspect of how learners learn through online discussions, such as social knowledge construction (Gunawardena et al., 1997), cognitive presence (Garrison, Anderson, \& Archer, 2001), critical thinking (Zhu, 1996) and so on. The new model contributes to the field of online research in that the model provides a coherent and comprehensive view of how learning occurs through online discussions. The model offers a guideline for researchers to further explore the nature of online discussions, develop instructional strategies to facilitate productive online discussions, and evaluate the quality of learning in online discussions. How the model should be used in online learning, however, varies depending on pedagogical goals and learners' experiences.

First, pedagogical goals for a course or a learning unit determine how the model should be applied in teaching practice. If the learning objectives are related to a certain disposition, the discussion activities can be aligned to this specific disposition and related actions in the model. That means the model can be implemented in any given order or combination based on the learning objectives of the course or unit. Instructors can decide to cover all four dispositions throughout one semester of discussion, or to require students to demonstrate all four dispositions in one single forum.

Second, learners'experiences also determine how the model can be implemented. For learners who are not skilled at online discussions, the model could be implemented in a way where students learn one or two dispositions first, and then more later. Learners can become involved in all the four dispositions as they gradually gain competence in online discussions.

The paper proposed a new model for online discussion, and discussed implications of the new model for research and instruction. In our future study, we will use empirical data to validate this model, and to investigate the effectiveness of this model by comparing it with other online discussion models.

\section{References}

Anderson, R. C., \& Biddle, W. B. (1975). On asking people questions about what they are reading. In G. H. Bower (Ed.), Psychology of learning and motivation (Vol. 9, pp. 89132). New York: Academic Press.

Anderson, T. (1996). The virtual conference: Extending professional education in Cyberspace. International Journal of Educational Telecommunications, 2, 121135.

Bridges, D. (1988). A philosophical analysis of discussion. In J. T. Dillon(Ed.), Questioning and discussion: An interdisciplinary study. Norwood, NJ: Ablex.

Chan, C. (2001). Peer collaboration and discourse patterns in learning from incompatible information. Instructional 
Science, 29(6), 443-479.

Chan, C., Burtis, J., \& Bereiter, C. (1997). Knowledge building as a mediator of conflict in conceptual change. Cognition and Instruction, 15, 1-40.

Chi, M. T., Bassok, M., Lewis, M. W., Reimann, P., \& Glaser, R. (1989). Self-explanations: How students study and use examples in learning to solve problems. Cognitive Science, 13, 145-182.

Chi, M. T., de Leeuw, N., Chiu, M., \& LaVancher, C. (1994). Eliciting selfexplanations improves understanding. Cognitive Science, 18, 439-477.

Chi, M. T., \& VanLehn, K. A. (1991). The content of physics self-explanations. The Journal of the Learning Sciences, 1, 69105.

Cho, K. L., \& Jonassen, D. H. (2002). The effects of argumentation scaffolds on argumentation and problem solving. Educational Technology Research \& Development, 50(3), 5-22.

Choi, I., Land, S. M., \& Turgeon, A. J. (2005). Scaffolding peer-questioning strategies to facilitate metacognition during online small group discussion. Instructional Science, 33, 483-511.

Collins, A., Brown, J. S., \& Larkin, K. M. (1980). Inference in text understanding. In R. J. Spiro \& B. C. B. W. F. Brewer (Eds.), Theoretical issues in reading comprehension (pp. 385-407). Hillsdale, NJ: Lawrence Erlbaum Associates.

Collison, G., Elbaum, B., Haavind, S., \& Tinker, R. (2000). Facilitating online learning: Effective strategies for moderators. Madison: Atwood Publishing.

Garrison, D. R., Anderson, T., \& Archer, W. (2000). Critical inquiry in a text-based environment: Computer conferencing in higher education. Internet and Higher Education, 2(2-3), 1-19.

Garrison, D. R., Anderson, T., \& Archer, W. (2001). Critical thinking, cognitive presence, and computer conferencing in distance education

American Journal of Distance Education, 15, 7-23.

Gunawardena, C. N., Lowe, C. A., \& Anderson, T. (1997). Analysis of a global on-line debate and the development of an interaction analysis model for examining social construction of knowledge in computer conferencing. Journal of Educational Computing Research, 17(4), 397-431.

Henri, F. (1992). Computer conference and content analysis. In A. Kaye (Ed.), Collaborative learning through computer conferencing (pp. 117-136). Berlin Springer-Verlag.

Hill, J. R., Song, L., \& West, R. E. (2009). Social learning theory and Web-based learning environments: A review of research and discussion of implications. The American Journal of Distance Education, 23(2), 88103.

Jeong, A., \& Joung, S. (2007). Scaffolding collaborative argumentation in asynchronous discussions with message constraints and message labels. Computers and Education, 48(3), 427-445.

Joeng, A. (2003). Sequential analysis of group interaction and critical thinking in threaded discussions. The American Journal of Distance Education, 17(4), 397-413.

Jonassen, D. (1991). Objectivism versus constructivism: Do we need a new philosophical paradigm? Educational Technology Research and Development, 39, 5-14.

Jonassen, D., Davidson, M., Collins, M., Compbell, J., \& Hagg, B. B. (1995). Constructivism and computer-mediated communication in distance education. The American Journal of Distance Education, 9, 7-26.

Kanuka, H., \& Anderson, T. (1998). Online social interchange, discord and knowledge construction. Journal of Distance 
Education, 13(1), 57-74.

Kanuka, H., Rourke, L., \& Laflamme, E. (2006). The influence of instructional methods on the quality of online discussion. British Journal of Educational Technology, 38(2), 260-271.

Lebaron, J., \& Miller, D. (2005). The potential of Jigsaw role playing to promote the social construction of knowledge in an online graduate education course. Teachers College Record, 107, 1652-1674.

Moore, J. L., \& Marra, R. M. (2005). A comparative analysis of online discussion participation protocols. Journal of Research on Technology in Education, 38(2), 191212.

Newman, D. R., Johnson, C., Cochrane, C., \& Webb, B. (1995). A content analysis method to measure critical thinking in face-to-face and computer supported group learning. Interpersonal Computing and Technology, 3(2), 56-77.

Nussbaum, E. M., Hartley, K., Sinatra, G. M., Reynolds, R. E., \& Bendixen, L. D. (2004). Personality interactions and scaffolding in on-line discussions. Journal of Educational Computing Research, 30, 113-136.

Palincsar, A. S. (1986). The role of dialogue in providing scaffolded instruction. Educational Psychologist, 21, 73-98.

Pena-Shaff, J. B., \& Nicholls, C. (2004). Analyzing student interactions and meaning construction in computer bulletin board discussions. Computers and Education, 42, 243-265.

Piaget, J. (1985). The equilibration of cognitive structure: The cental problem of intellectual development. Chicago: The University of Chicago Press.

Pressley, M., Wood, E., Woloshyn, V. E., \& Martin, V. (1992). Encouraging mindful use of prior knowledge: Attempting to construct explanatory answers facilitates learning. Educational Psychologist, 27, 91109.
Redfield, D., \& Rouseau, E. (1981). A metaanalysis of experimental research on teacher questioning behavior. Review of Educational Research, 51, 237-245.

Rourke, L., \& Anderson, T. (2002). Using peer teams to lead online discussion [Electronic Version]. Journal of Interactive Media in Education, 1 from http://www-jime.open. ac.uk/2002/1/

Samson, G., Strykowski, B., Weinstein, T., \& Walberg, H. (1987). The effects of teacher questioning levels on student achievment: A quantitative synthesis. The Journal of Educational Research, 80, 290-295.

Scardamalia, M., \& Bereiter, C. (1994). Computer support for knowledge-building communities. The Journal of the Learning Sciences, 3(3), 265-283.

Scardamalia, M., \& Bereiter, C. (2003). Knowledge building environments: Extending the limits of the possible in education and knowledge work. In A. DiStefano, K. E. Rudestam \& R. Silverman (Eds.), Encyclopedia of distributed learning (pp. 269-272). Thousand Oaks, CA: Sage.

Spatariu, A., Hartley, K., \& Bendixen, L. D. (2004). Defining and measuring quality in online discussions. Journal of Interactive Online Learning, 2(4), 1-15.

Suthers, D., Weiner, A., Connelly, J., \& Paolucci, M. (1995). Belvedere: Engaging students in critical discussion of science and public policy issues. Paper presented at the 7th World Conference on Artificial Intelligence in Education.

Tallent-Runnels, M. K., Thomas, J. A., Lan, W. Y., Cooper, S., Ahern, T. C., Shaw, S. M., et al. (2006). Teaching courses online: A review of the research. Review of Educational Research, 76(1), 93-135.

Thomas, M. J. W. (2002). Learning within incoherent structures: The space of online discussion forums. Journal of Computer Assisted Learning, 18, 351-366.

VanLehn, K., Jones, R. M., \& H., C. M. T. 
(1992). A model of the self-explanation effect. Journal of the Learning Sciences, 2, $1-59$.

Webb, N. (1991). Task-related verbal interaction and mathematics learning in small groups. Journal for Research in Mathematics Education, 22(5), 366-389.

Wever, B., Schellens, T., Valcke, M., \& Keer, H. (2006). Content analysis schemes to analyze transcripts of online asynchronous discussion groups: A review. Computers and Education, 46(1), 6-28.

Wong, B. Y. (1985). Self-questioning instructional research. Review of Educational Research, 55, 227-268.

Yang, Y. C., Newby, T. J., \& Bill, R. L. (2005). Using Socratic questioning to promote critical thinking skills through asynchronous discussion forums in distance learning environments. The American Journal of Distance Education, 19(3), 163-181.

Zhu, E.(1996). Meaningnegotiation, knowledge construction, and mentoring in a distance learning course. Paper presented at the National Convention of the Association for Educational Communications and Technology.

\section{Contact the Authors}

Fei Gao, Ph.D.

Montclair State University, USA

E-mail: gaof@mail.montclair.edu

Charles Xiaoxue Wang, Ph.D

Georgia State University, USA

E-mail: xwang10@gsu.edu

Yanling Sun, Ph.D.

Montclair State University, USA

E-mail: suny@mail.montclair.edu 